\title{
Selecting farm practices and preparing farm plans for land-use consents in the Manawatu-Wanganui region
}

T.G. PARMINTER

KapAg Ltd, PO Box 354, Paraparaumu, Kapiti Coast 5254

terry.parminter@kapag.nz

\begin{abstract}
Throughout 2014, the Manawatu-Wanganui Regional Council and DairyNZ worked with 10 farm consultants assisting dairy farmers preparing farm plans for the regional OnePlan and reducing their risks of contaminating local waterways. Twenty-three farm plans that had been produced with the support of five farm consultants were examined. Starting with average annual leaching losses of $23-71 \mathrm{kgN} / \mathrm{ha}$, these plans included a range of mitigation practices to achieve reductions in nitrate losses of 5-15\%. Although they had been developed independently, similar practices were bundled together in the plans to match the needs of each farmer's circumstances and particular farming systems. This work suggests that although a short list of mitigation practices may be able to be selected for application on farms, the impact of those practices upon each farm business will each need to be determined in order to reliably enhance farm sustainability and viability across a catchment.
\end{abstract}

Keywords: consultancy, OnePlan, consents, farming systems

\section{Introduction}

In response to a rising level of general concern amongst farmers when the OnePlan was being introduced, the Manawatu-Wanganui Regional Council, DairyNZ, farm consultants and other agencies developed an implementation approach to support dairy farmers in the region engaged in the process of developing consent applications so that they could continue dairy farming. To test this, a pilot project was initiated in 2014 with several aims. It was intended to provide the industry and individual farmers with practical ways of mitigating the effects of dairy farming upon waterway quality; it would assist farmers in regional subcatchments prepare their land use consents, and it would do this as efficiently as possible and for the minimum cost. This paper describes the contribution made by individual farm consultants towards the realisation of these aims. This paper doesn't address the nature of the discussions that farm consultants had with farmers or the appropriateness of the advice, but rather focusses on the structural and institutional issues that were associated with implementing on-farm regional council policies. The introduction provides some background about the policy context for this work, but the science of water quality and the attribution of apparent waterway degradation have been left to other papers and particularly to the evidence presented at the Environment Court proceedings that considered the OnePlan regulations.

The OnePlan for the Manawatu-Wanganui Region combines the regional policy statement, the regional coastal plan and the regional plan into a single document (Manawatu-Wanganui Regional Council 2014a). For the first time in that region it contained rules about nutrient management on intensive farms, including irrigated sheep and beef farms as well as dairy farms. In the section of the OnePlan addressing nutrient management (chapter 14), existing dairy farmers in 29 water management subzones across the region, as well as all newly established dairy farms throughout the region, were required to apply for a landuse consent and submit a nutrient management plan. The water management subzones have been estimated to encompass $14 \%$ of the region's total land area (or 315898 ha; Bell \& McDonald 2013). In the affected catchments were almost $50 \%$ of the total dairy farms in the region (or 440 farms).

The OnePlan requires the use of a decision support software in order to prepare farmers' nutrient management plans, to monitor progress in implementing the plans on farms and to enforce farmer consents. Overseer ${ }^{\circledR}$ was the regulated software, a science based nutrient model developed by crown and industry agencies (Wheeler et al. 2003 and subsequent). Evidence about the use of Overseer by the dairy industry was presented to the Environment Court during its hearings on the OnePlan (ManawatuWanganui Regional Council 2010). After deliberating on the evidence, the Environment Court upheld the use of Overseer as described in the OnePlan.

The introduction of the OnePlan has been highly contentious and the Regional Council received submissions about it from Federated Farmers, Fonterra, NZ Fertiliser Manufacturers' Research Association, Royal Forest and Bird Protection Society of New Zealand, Fish \& Game, other organisations and individual landowners (Manawatu-Wanganui Regional Council 2014b). To resolve these issues the 
OnePlan went first before a panel with independent commissioners and then before the Environment Court. However introducing the OnePlan remained problematic for the Regional Council. Having to apply for a landuse consent, as these consents became known as, was considered to be quite an onerous process for the dairy industry and a burden on individual farmers (Rural News 2012). Eventually the Regional Council decided that existing dairy farmers in the subzones and all new dairy farms in the region would need to apply for controlled consents only if they could meet the nutrient targets described in the OnePlan Table 14.2. In all other cases farmers needed to apply for a discretionary consent for up to 20 years showing that they were following industry best practice for farming systems like theirs.

\section{Methods}

In order to quantify the possible financial burden upon farming in the region and inform the Regional Council's decision making about implementation of the OnePlan, an economic study was undertaken in 2013, guided by DairyNZ, the Regional Council and the Tararua Business Group (Bell \& McDonald 2013). The study analysed three implementation options using the financial results from fourteen farms selected to represent dairy farming in the region. A linear program was used to optimise individual farm systems and a cost benefit analysis undertaken to assess the direct impacts on the dairy sector within the region. In the report three future scenarios (options) were evaluated. Scenario 1 assumed that all farms would be required to operate within the leaching maximums specified in Table 14.2 of the OnePlan. In the report this option was modelled to reduce nitrate leaching by about $30 \%$ and calculated to reduce annual farm profit by $5-45 \%$. The second scenario assumed that farmers could adapt their landuses and farming systems to minimise nitrate losses but without decreasing their annual profitability by more than $10 \%$. In the calculations after this option had been modelled, nitrate leaching was reduced by about $25 \%$ without any calculated overall change in profitability. The third scenario to be tested assumed that without changing their existing systems, their production or profitability, farmers would still be able to achieve the Regional Council's catchment targets by making marginal practice changes in order to minimise nitrate leaching. Modelling the third option resulted in a reduction in nitrate leaching of about $20 \%$ although operating profitability was also reduced by about $5 \%$ per annum. For the Regional Council, the third option was the least disruptive way to modify current farming systems, it utilised existing farmer capabilities, and it could be quickly extended across the region. Therefore the Council decided to develop an implementation plan around the third option.

In January 2014 a number of private consultants were invited to participate in a pilot study to work one-toone with 50 dairy farmers preparing nutrient budgets in the Mangatainoka, Mangapapa and Waikawa Water Management Sub-zones. All the consultants were required to be locally known by farmers in the region, be certified in advanced Overseer by Massey University and have proven farming system capability. The farmers were volunteers selected by DairyNZ. All the nutrient budgets were to be completed by the end of 2014 and submitted to Manawatu-Wanganui Regional Council for approval by the consenting team.

In the project the consultants assisted each farmer to prepare a consent application, and a supplementary report with information supporting the consent application, and provide a nutrient management plan. In all cases the practices to be changed were advised by the farm consultants but chosen by the participating farmers. This information was sent by the farmer clients to Manawatu-Wanganui Regional Council. In addition, the consultants prepared an implications plan for each farmer with partial budgets describing the impact upon each farm (over the long term) of introducing or changing possible mitigating practices. The costs and returns in these were based on those being realised by the farmers themselves and a long term return of $\$ 6.50$ / $\mathrm{kg}$ milk solids.

In early 2015, in preparation for this paper, all nine farm consultants in the pilot project were asked if they could provide copies of the management reports that they had prepared for their farmer clients. These reports were reviewed against the purposes of the pilot project to identify the overall contribution by the dairy industry towards creating future opportunities for dairying in the region whilst reducing its environmental footprint. The review of the management reports examined three measures able to be provided in the reports by the participating consultants. The type and range of practices and the order in which they were introduced was used as a measure of the practicality of practice change. The reduction in estimated nitrate leaching was used as a measure of the environmental impact of making these changes. The time taken to prepare the consent applications provided an estimate of their likely cost.

\section{Results}

By the end of 2014 in the pilot project a total of 39 consents from farmers had been submitted to ManawatuWanganui Regional Council for their approval. Five farm consultants then participated in preparing this paper using results from all 23 farms that they had completed. The farms had an average estimated nitrate leaching loss of $40 \mathrm{~kg} \mathrm{~N} / \mathrm{ha}$ in Overseer version 6.1, 
ranging from a low of $23 \mathrm{~kg}$ $\mathrm{N} / \mathrm{ha}$ to a high of $71 \mathrm{~kg} \mathrm{~N} / \mathrm{ha}$. The dairy platforms ranged in size from 85 ha to 405 ha with type 2,3 , and 4 dairy systems (Shadbolt 2011).

Typically the consultants spent about 24 hours working with each of their clients to analyse the management options, prepare their reports and then assist with the consent application. A similar amount of time had already been spent by Regional Council staff and DairyNZ to prepare farm maps and a base nutrient budget for each farm.

The farmers and their consultants identified a range of mitigation practices (Figure 1). Between one and three practices were addressed on each farm. The choice of practices and the number selected by each farmer depended on the available potential for change in each farmer's system and their level of enthusiasm for accommodating the purposes of

\begin{tabular}{|c|c|c|c|}
\hline $\begin{array}{l}\text { Replace autumn } \\
\text { nitrogen with } \\
\text { giberellin product }\end{array}$ & Increase effluent area & $\begin{array}{l}\text { Replace spring } \\
\text { nitrogen with } \\
\text { giberellin product }\end{array}$ & $\begin{array}{l}\text { Change nitrogen } \\
\text { from winter to } \\
\text { autumn }\end{array}$ \\
\hline $\begin{array}{l}\text { Graze-off } 15-30 \% \\
\text { of herd over winter }\end{array}$ & $\begin{array}{l}\text { Hold farm production } \\
\text { and reduce cow } \\
\text { numbers by } 5 \%\end{array}$ & $\begin{array}{l}\text { Replace autumn } \\
\text { nitrogen with } \\
\text { giberellin product }\end{array}$ & $\begin{array}{l}\text { Replace fodder crop } \\
\text { with chicory }\end{array}$ \\
\hline $\begin{array}{l}\text { Replace cropping } \\
\text { with silage and PKE }\end{array}$ & $\begin{array}{l}\text { Fence-off Class VI, } \\
\text { with riparian planting }\end{array}$ & $\begin{array}{l}\text { Replace both spring } \\
\text { and autumn nitrogen } \\
\text { with giberellin } \\
\text { product }\end{array}$ & $\begin{array}{l}\text { Replace fodder crop } \\
\text { with silage }\end{array}$ \\
\hline $\begin{array}{l}\text { Replace autumn } \\
\text { nitrogen with } \\
\text { imported silage }\end{array}$ & & $\begin{array}{l}\text { Hold farm production } \\
\text { and reduce cow } \\
\text { numbers by } 15 \%\end{array}$ & \\
\hline $\begin{array}{l}\text { Replace nitrogen } \\
\text { fertiliser with maize } \\
\text { silage from off-farm }\end{array}$ & $\begin{array}{l}\text { Construct a covered } \\
\text { feedpad }\end{array}$ & $\begin{array}{l}\text { Replace nitrogen } \\
\text { fertiliser with } \\
\text { grazing-off } 100 \% \text { of } \\
\text { cows over winter }\end{array}$ & In-shed grain feeding \\
\hline $\begin{array}{l}\text { Improve farm } \\
\text { subdivision }\end{array}$ & & $\begin{array}{l}\text { Replace nitrogen } \\
\text { fertiliser with PKE }\end{array}$ & \\
\hline $\begin{array}{l}\text { Replace } 20 \% \text { of } \\
\text { nitrogen with silage } \\
\text { from off-farm }\end{array}$ & & $\begin{array}{l}\text { Replace cropping } \\
\text { with silage and PKE }\end{array}$ & \\
\hline Reduce cows by $13 \%$ & & $\begin{array}{l}\text { Graze-off } 30-70 \% \\
\text { of herd over winter }\end{array}$ & \\
\hline
\end{tabular}

Figure 1 Mitigation practices included by farmers in their consent applications and their relative priority (1=highest priority). PKE $=$ Palm kernel extract the OnePlan. In part, the farmers

based their decisions on the information provided to them by the farm consultants. In the figure, the first cell lists the seven practices that were given the highest priority across all the farms. Where suitable, the highest priority was to reduce the number of nitrogen fertiliser applications made in a year and the total amount of nitrogen fertiliser applied. In other farm situations it was possible to reduce losses by reducing the amount of cultivation associated with growing forage crops.

Some farmers were able to reduce cow-calving numbers (without them expecting to reduce their total production) or to reduce wintering stock numbers. On farms where a minimal cost was involved, farmers prioritised an increase in their effluent application area or fenced-off their steeper class VI land. These changes reduced estimated nitrate loses by $<1-25 \%$. They cost between $\$ 0.2-18 / \mathrm{kg}$ reduction in nitrate leaching (an average of $\$ 7 / \mathrm{kg} \mathrm{N}$ ). However, on the farm where a stocking rate reduction was selected there was an estimated net benefit of $\$ 5 / \mathrm{kg} \mathrm{N}$.

On some farms the farmers considered that it was possible for them to make an additional management change to further reduce likely nitrate losses. These management practices are listed in the second cell of the figure. Again, most of the changes involved further modifying and reducing the amount of nitrogen fertiliser being applied. The changes were estimated to reduce nitrate leaching losses by a further $5 \%$ and cost an average of $\$ 9 / \mathrm{kg} \mathrm{N}$.

On some of the farms a third management change was considered possible by the farmers. These changes tended to involve replacing a high protein feed with a relatively low protein feed and reducing livestock numbers. The third practice change could reduce nitrate leaching by an additional 5\%. Feed replacement policies cost on average $\$ 25 / \mathrm{kg} \mathrm{N}$ and a change in stock numbers could actually increase profitability as long as by doing so total production was maintained while overall operating costs were reduced. A few farmers could identify a fourth management change. These were similar but additional to the management changes made earlier on other farms. The possible nitrate reductions were just over $5 \%$ and they cost on average $\$ 25 / \mathrm{kg} \mathrm{N}$.

In total, the farm consultants estimated that it was possible to achieve nitrate reductions of between $5-25 \%$ on the farms, averaging $13 \%$ across all the farms. The impact of this upon water quality in the region will be monitered over the next few years by Manawatu-Wanganui Regional Council. Introducing these mitigations with the exception of the livestock 
reductions (which had a positive effect) was estimated to cost each of these farmers over $\$ 6500$ annually (on average $\$ 37 / \mathrm{ha}$ ).

\section{Discussion and Conclusion}

The contribution of farm consultants to New Zealand's research, development and extension has been studied and found to be extremely variable (Botha et al. 2006). Generally farm consultants were considered to be highly capable in financial and technical advice but lacked environmental capability. The authors of that paper considered that farm consultants needed "new forms of ... consultancy" in order to integrate environmental issues with the production aspects of their advice. The pilot project reported in this paper involved farm consultants, the regional council and DairyNZ working together in a new way for dairy farmers in the Manawatu-Wanganui region and it may be the beginning of a farm consultancy service that goes beyond its expected constraints.

The results of this paper provide a cross-section of the information being used by farmers and consultants in their decision making on dairy farms. The study did not include management reports from all the farmers in the pilot project and not all the management practices identified here will have made it through the consenting process. For various reasons some management practices may have been subsequently dropped by farmers or the staff at Manawatu-Wanganui Regional Council.

Each consent application and its associated reports has taken about three days to prepare by a farm consultant. The amount of time was highly variable and some farms in this study took twice that amount of time. This is a considerable amount of time and it indicates that identifying and describing the mitigations that individual farmers may best employ to reduce their nitrate leaching is information-intensive and complex. A number of iterations in the analyses may be required before a suitable combination of practices can be selected.

From the results of the pilot study it is apparent that dairy farmers in the Manawatu-Wanganui region typically require two to four practice changes within their current farming systems before they achieve significant nitrate reductions on their properties. Overall the amount of reduction possible without requiring significant capital investment or system changes was less than those estimated in the cost benefit report prepared on the OnePlan (Bell \& McDonald 2013). However the cost of the mitigations to the individual farmers was also a lot less than had been predicted. That suggests that practical and sustainable strategies are being devised. Not identified in this study is the decision making processes used by farmers and consultants to select their practices and to determine their relative priority. This appears to be related to the strengths and weaknesses of each farming system, and the experience and capability of the farmers involved (and their staff).

Although each of the farm consultants was operating independently of the others, a relatively consistent set of practice changes was introduced in each farm plan from nitrogen fertiliser use to cropping and supplementary feeding. In general the economic and management effects of making these changes were kept within-season. However by constraining their potential application in the future, the tactical options available to farmers for coping with extreme seasons, e.g., drought, become more limited. Almost all the farmers discussed the advantages of making capital investments during the consenting period to secure their future productivity gains, make it easier for them to comply with OnePlan regulations and to provide them with management flexibility. These investments could include changing their effluent system, facilities for holding cows offpaddock, track design, stream crossings, and land purchase. Some of these investments appeared in Figure 1.

Some previous papers and reports describing practice change amongst farmers for environmental outcomes have been written in anticipation of the actual decisions for change being made. For example Park et al. (2014), describing the participation by local Lake Rotorua farmers in a project to "promote adoption of nitrate mitigation methods". Other papers and reports have described the environmental gains at catchment scales obtained from agricultural extension changes without describing the on-farm changes or extension activities themselves. For example Monaghan et al. (2009), describe the results of practice change by over 30 dairy farmers on water quality in four dairy catchments over a period of 8 years. In this paper it is hoped that a description of the actual consenting process may provide some guidance for future research investment into farmer decision making processes.

\section{ACKNOWLEDGEMENTS}

The author appreciated the opportunity that was provided by DairyNZ and Manawatu-Wanganui Regional Council to participate in this pilot study. The contributions of collaborating consultants were crucial to preparing this paper: Stefan Bryant, Brian Clarke, Scott Ridsdale, and John Stantiall.

\section{REFERENCES}

Bell, B.; McDonald, G. 2013. Cost benefit and economic analysis of the Horizons OnePlan. NimmoBell and Company Ltd and Market Economics Ltd, Wellington, New Zealand. 
Botha, N., Coutts, J., Roth, H. 2006. The role of agricultural consultants in the New Zealand research, development and extension system. In: Proceedings of the New Zealand Agricultural and Resource Economics Society, Nelson, New Zealand.

Manawatu-Wanganui Regional Council 2010. Submitter expert evidence: water hearing. http:// www.horizons.govt.nz/assets/one-plan-publicationsand-reports/SWQ-Technical-Evidence-StewartLedgard-20120314.pdf. Accessed 1 July 2015.

Manawatu-Wanganui Regional Council 2014a. One Plan. The consolidated regional policy statement, regional plan and regional coastal plan for the Manawatu-Wanganui region. Horizons Regional Council, Palmerston North, New Zealand.

Manawatu-Wanganui Regional Council 2014b. Documents that shaped the One Plan. http://www. horizons.govt.nz/about-us/one-plan/overview/ documents-that-shaped-the-one-plan/. Accessed 30 June 2015.

Park S., Kingi T., Morrell S., Metheson L., Ledgard S. 2014. Nitrogen losses from Lake Rotorua dairy farms - modelling, measuring and engagement.
In: Nutrient management for the farm, catchment and community. Eds Currie, L.D.; Christensen, C.L. $\quad$ http://flrc.massey.ac.nz/publications.html. Occasional Report No. 27. Fertilizer and Lime Research Centre, Massey University, Palmerston North, New Zealand. 11 pages.

Rural News 2012, One Plan 'a dog'. http:// ruralnewsgroup.co.nz/rural-news/rural-generalnews/one-plan-a-dog. Accessed 20 May 2015.

Shadbolt, N.M., 2011. Competitive strategy analysis of NZ pastoral farming systems. pp 122-132 In: 18th International Farm Management Congress vol. 1

Monaghan, R.; Wilcock, R.; Smith, C.; Houlbrooke, D.; McGowan, A.; Quinn, J.; Bramley, M.; Rutherford, C.; Cotton, S. 2009. Best practice dairy catchments study: Summary report to SFF. An AgResearch client report for the Ministry of Agriculture and Fisheries.

Wheeler, D.M.; Ledgard, S.F.; De Klein C.A.M.; Monaghan R.M.; Carey P.L.; McDowell R.W.; Johns, K.L. 2003. OVERSEER $\AA$ nutrient budgets - moving towards on-farm resource accounting. Proceedings of the New Zealand Grassland Association 65: 191194. 
